\title{
Aplikasi pengendalian hayati untuk penyakit parasitik pada Kerbau Rawa di Desa Tanjung Pering Kecamatan Inderalaya Kabupaten Ogan Ilir
}

\author{
Afnur Imsya ${ }^{(\mathbb{D})}$, Yuanita Windusari ${ }^{(\mathbb{D})}$, Laila Hanum, \& \\ Hikayati
}

Universitas Sriwijaya, Indonesia

*aimsya@yahoo.com

\begin{abstract}
One of the problems that occur in buffalo farms in tanjung pering village is that buffaloes often experience health problems caused by parasites. The results of initial observations showed that livestock showed symptoms such as dry skin, hair loss, loss of appetite, lethargy and finally decreased productivity and even death. This disease often appears during the transition from the rainy season to the dry season. Based on the results of research that has been carried out on faecal samples of swamp buffalo in the villages of tanjung pering and tanjung senai, the identification of the presence of parasite eggs of cestode, nematode and trematode. This activity aims to provide knowledge innovation to the farming community in tanjung pering village about the methods and importance of biological control as an alternative to controlling the spread of parasitic diseases. The methods used in this activity are counseling, training in the form of demonstrations and activity evaluations. The results of the extension activities show that there is an increase in the understanding of farmers about the causes and symptoms of the disease, how to handle and biological control of parasites by using the nematophagus fungus. The conclusion of this activity is the existence of continuous application of disease control using biological agents to suppress livestock populations experiencing parasitic infections.
\end{abstract}

Abstrak Permasalahan Peternakan kerbau Di Desa Tanjung Pering adalah ternak
kerbau sering mengalami gangguan kesehatan disebabkan oleh parasite. Hasil
observasi awal ternak menunjukkan gejala kulit yang kering, bulu rontok,
kehilangan nafsu makan, lesu dan produktifitas menurun bahkan sampai
mengalami kematian. Penyakit ini muncul waktu peralihan musim hujan ke
musim kemarau. Berdasarkan hasil penelitian yang dilakukan pada sampel feses
kerbau rawa di desa Tanjung Pering didapatkan hasil identifikasi adanya telur
parasite Cestoda, nematoda dan Trematoda. Salah satu pengendali hayati yang
pontensial untuk penyakit parasite yaitu jamur Nematofagus. Kegiatan ini
bertujuan memberikan inovasi pengetahuan pada peternak di desa Tanjung
Pering tentang cara dan pentingnya pengendalian hayati sebagai salah satu
alternative untuk mengendalikan penyebaran penyakit parasite. Metode yang
digunakan dalam kegiatan ini adalah penyuluhan, pelatihan berupa demonstrasi
dan evaluasi kegiatan. Hasil kegiatan menunjukkan bahwa setelah dilakukan
kegiatan pengabdian ini hampir $90 \%$ peternak memahami penyebab dan gejala
penyakit, $85 \%$ memahami cara penanganan penyakit dan $75 \%$ melakukan
pengendalian hayati dari parasite dengan menggunakan Nematofagus.
Kesimpulan kegiatan adalah adanya penimgkatan pemahaman peternak tentang

\section{OOPEN ACCESS}

Citation: Imsya, A., Y. Windusari., L. Hanum., \& Hikayati. (2021). Aplikasi pengendalian hayati untuk penyakit parasitik pada Kerbau Rawa di Desa Tanjung Pering Kecamatan Inderalaya Kabupaten Ogan Ilir. Riau Journal of Empowerment, 4(3), 165-173.

https://doi.org/10.31258/raje.4.3.165-173

Received: 021-07-12 Revised: 2021-12-27 Accepted: 2021-12-28

Language: Bahasa Indonesia (id)

ISSN 2623-1549 (online), 2654-4520 (print)

(C2021 Afnur Imsya, Yuanita Windusari, Laila Hanum, \& Hikayati. Author(s) retain the copyright of article published in this journal, with first publication rights granted to Riau Journal of Empowerment. The article is licenced under Creative Commons Attribution 4.0 International License. This license permits unrestricted use, distribution, and reproduction in any medium, provided the original author and source are credited. 
penyebab dan gejala penyakit, cara penanganan serta penggunaan agen hayati untuk pengendalian infeksi parasite.

Keywords: parasitologists; biological control; nematophagus; pampangan buffalo 
Desa Tanjung Pering terletak di kecamatan Indralaya Utara Kabupaten Ogan Ilir Provinsi Sumatera Selatan. Kecamatan Indralaya Utara memiliki ketinggian tempat 4 - 6 Meter diatas permukaan laut, dengan wilayah daratan mencapai $55 \%$ dan wilayah perairan atau rawa-rawa mencapai $45 \%$. Derajat keasaman telah berkisar antara 4,8-6,0. Pada kawasan bagian utara terdapat areal rawa-rawa yang sangat luas, dalam dan keasaman yang tinggi sehingga sulit untuk dimanfaatkan sebagai lahan pertanian. Sebagian besar lahan rawa digunakan bagi peternak sebagai tempat penggembalaan kerbau Rawa (Pampangan)

Permasalahan yang terjadi di Peternakan kerbau Di Desa Tanjung Pering salah satunya adalah seringnya ternak kerbau mengalami gangguan kesehatan yang disebabkan oleh parasite, dari hasil observasi awal diperoleh informasi dari peternak bahwa ternak sering kali menunjukkan gejala seperti kulit yang kering, bulu rontok, ternak kehilangan nafsu makan, lesu dan akhirnya produktifitas menurun bahkan sampai mengalami kematian. Penyakit ini sering kali muncul pada saat peralihan dari musim hujan ke musim kemarau. Berdasarkan hasil penelitian Windusari Y. et al., (2018) yang telah dilakukan pada sampel feses kerbau rawa di desa Tanjung Pering dan Tanjung Senai didapatkan hasil identifikasi adanya telur parasite Cestoda, nematoda dan Trematoda. Penyakit parasit cacing secara ekonomis merugikan, akibat penyakit ini adalah hambatan pertambahan berat tubuh ternak. Parasit cacing merugikan ternak kerbau karena cacing menyerap sebagian zat makanan yang diperlukan untuk pertumbuhan tubuh ternak, merusak jaringan-jaringan organ vital ternak dan menyebabkan nafsu makan ternak kerbau berkurang.

Pengendalian penyakit parasite dapat dilakukan dengan pengobatan kimia, hanya saja aspek negatif dari metode ini adalah resiko efek kerusakan lingkungan pada organisme yang bukan sasaran, konsentrasi residu dalam produksi dan resiko untuk berkembangnya resistensi pada patogen terhadap antibiotik atau obat kimia yang diberikan. Selain itu bahan kimia baru sangat mahal untuk dikembangkan. Alternatif lain yang dapat dilakukan yaitu dengan pengendalian hayati. Agen pengendali hayati jarang membasmi organisme sasaran, tetapi mengurangi gejala yang timbul sampai level yang dapat diterima dan mempertahankan keseimbangan antara patogen dan organisme sasaran. Musuh alami untuk menekan populasi organisme sasaran. Agen pengendali hayati pada umumnya diharapkan tidak mengganggu organisme yang bukan sasaran atau memicu perkembangan resistensi. Tampubolon (2004) menyatakan bahwa pengendalian hayati adalah manipulasi secara langsung dan sengaja dari musuh alami, pesaing organisme pengganggu, seluruhnya atau sebagian, atau sumber daya yang diperlukan oleh agen itu untuk pengendalian organisme pengganggu atau dampak negatifnya.

Permasalah penyakit parasite pada ternak kerbau di desa Tanjung Pering, pada dasarnya dapat dikendalikan dengan pengendali hayati salah satunya dengan menggunakan jamur Nematofagus. Jamur Nematofagus merupakan jamur yang dapat menghancurkan nematoda. Jamur ini terdiri dari lebih dari 200 spesies jamur dengan taksonomi beragam yang semua berbagi kemampuan untuk menyerang nematoda hidup (remaja, dewasa dan telur) dan menggunakannya sebagai nutrisi (Hertz et al., 2011). Aplikasi suatu strategi pengendalian hayati tidak semata-mata masalah perubahan teknik dari suatu kimiawi ke arah suatu agen biologis, tetapi keseimbangan yang banyak perubahan dalam sikap dan harapan. Pengguna harus mengetahui biologi (dinamika populasi dan ekologi) dari organisme pengganggu dan agen pengendali hayati, supaya memilih waktu yang tepat untuk perlakuan. Beradasarkan hal tersebut diatas maka dirasakan perlu untuk melakukan pengabdian pada masyarakat tentang 
pengendalian hayati untuk penyakit parasite yang banyak menyerang pada ternak kerbau di Desa Tanjung Pering, dengan inovasi pemanfaatan jamur Nematofagus sebagai agen pengendali hayati. Kegiatan ini bertujuan untuk memberikan inovasi pengetahuan pada masyarakat peternak di desa Tanjung Pering tentang cara dan pentingnya pengendalian hayati sebagai salah satu alternative untuk mengendalikan penyebaran penyakit parasite.

\section{METODE PENERAPAN}

Metode yang digunakan dalam kegiatan program ini berupa penyuluhan dan pelatihan Adapun tahapan kegiatan yaitu tahap persiapan, pelatihan dan demonstrasi, pendampingan pada peternak dan evaluasi:

1. Tahap persiapan, tahap ini dalakukan dengan pendekatan pada aparat desa, pemuka masyarakat, anggota kelompok tani peternak dan koordinasi Tim dengan pihak terkait lainnya.

2. Pelatihan dan demonstrasi

Pada tahapan awal pelatihan peserta akan diberikan kuisioner berupa pertanyaan terkait penyakit parasite, penyebab, pencegahan dan pengobatan yang terdapat di desa Tanjung Pering, pengetahuan tentang pengendalian hayati seperti jamur Nematofagus. Selanjutnya peternak diberi penjelasan terkait dengan penyakit parasite yang menyerang ternak kerbau, mulai dari penyebab, gejala, cara pencegahan dan pengendalian terutama dengan menggunakan agen hayati seperti jamur Nematogagus serta pengobatan

3. Percontohan pelaksanaan pengendalian hayati pada kandang ternak.

Pada tahapan ini peternak diberi percontohan cara penerapan jamur Nematofagus untuk pengendalian hayati penyakit ternak parasitologis pada kendang dan lahan pengembalaan ternak Kerbau Rawa yang dilakukan dengan menghancurkan bolus Nematofagus dan dilakukan penyebaran spora pada padang pengembalaan dan disekitar kendang, terutama pada area yang basah dan lembab.

4. Pendampingan.

Kegiatan pendampingan dilakukan pada peternak yang memiliki ternak kerbau baik yang ternak kerbaunya mengalami inkfesi parasite maupun yang tidak, dalam hal penerapan pengedali hayati berupa jamur Nematofagus pada kendang dan lahan pengembalaam ternak kerbau

5. Evaluasi kegiatan

Evaluasi dilakukan setelah kegiatan pengabdian selesai dilaksanakan dengan pemberian kuisioner yang pertanyaan sama dengan kuisioner pada saat sebelum pelatihan. Hal ini dilakukan untuk melihat dampak kegiatan pengabdian pada peningkatan pemahaman peternak tentang pengendalian hayati terhadap penyakit parasite

\section{HASIL DAN KETERCAPAIAN SASARAN}

\section{Tingkat pemahaman peternak di Desa Tanjung Pering terkait penyebab dan gejala penyakit parasite pada ternak Kerbau}

Penyakit parasite pada ternak kerbau merupakan penyakit yang disebabkan oleh adanya parasit yang menyebabkan infeksi pada ternak. Penyakit ini muncul karena kondisi lingkungan dan 
manajemen pemeliharaan ternak yang tidak baik, hal ini dipengaruhi juga oleh pengetahuan tentang pentingnya manajemen sanitasi untuk pemeliharaan ternak. Dari data survey awal diketahui bahwa sebagian besar peternak (45\%) tidak mengetahui penyebab penyakit yang disebabkan oleh kondisi lingkungan dan kebersihan ternak sehingga manajemen kebersihan ternak dan lingkungan ternak sering kali tidak diperhatikan. Widyana (2013) menyatakan penyakit parasite biasanya menyerang ternak yang muda, yang dipelihara kurang baik seperti tidak pernah dikandangkan, tidak pernah dimandikan dan digembalakan pada lahan yang tergenang air. Kurangnya perhatian peternak terhadap manajemen pemeliharaan ternak karena sebagian peternak masih dalam skala usaha sampingan. Pengelolaan peternakan secara tradisional dan baru menjadi usaha sampingan sering kali tidak ada intervensi dalam kesehatan ternak (Gayatri \& Vaarst, 2015). Kondisi pengelolaan peternak yang seperti itu akan menyebabkan rentannya ternak mengalami penyakit infeksius seperti infeksi parasite (Nurhidayah et al., 2019). Setelah dilakukan kegiatan pengabdian kepada masyarat maka pengetahuan peternak tentang penyebab penyakit terutama penyakit disebabkan oleh infeksi parasite meningkat menjadi $90 \%$, memahami bagaimana kondisi manajemen lingkungan akan sangat mempengaruhi kesehatan ternak.

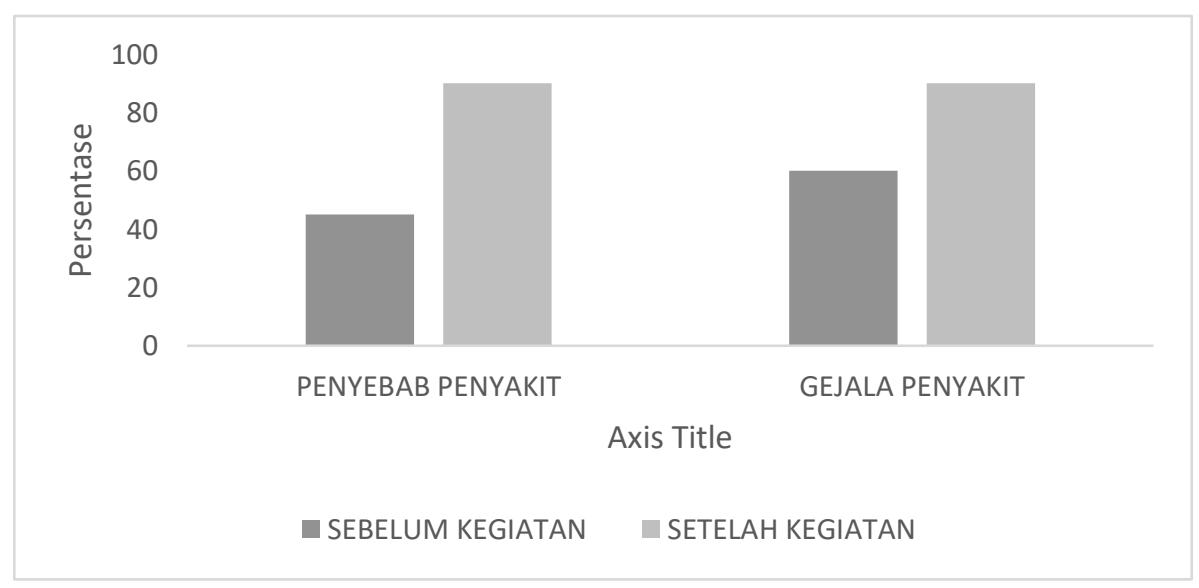

Gambar 1. Tingkat Pemahaman Peternak Tentang Penyakit Parasite

Infeksi penyakit parasite seperti cacing pada ternak kerbau akan menunjukkan gejala seperti ternak akan menjadi lemah, bulu kusam, bobot badan lama kelamaan akan menurun, pada kondisi yang lama maka gejala akan meningkat pada tahap terjadinya anemia, diare dan kematian (Tiuria et al., 2008). Hampir 60\% peternak ditanjung pering sudah memahami gejala saat ternak mengalami infeksi parasite cacing yang kadang muncul saat terjadinya perubahan dari musim hujan ke musim kemarau, setelah kegiatan pengabdian dilakukan maka hampir semua peternak (90\%) (Gambar. 1) sudah memahami gejala penyakit yang disebabkan oleh parasite cacing.

Pada kegiatan ini dijelaskan juga pada peternak untuk menjaga sanitasi kandang, minuman dan pakan sebagai upaya pencegahan pemyakit parasite cacing. Sanitasi kendang bisa dilakukan dengan mengurangi kelembaban, mengurangi air yang tergenang disekitar kendang sehinga kendang tidak terlalu basah. Seperti yang dinyatakan oleh Subekti et al., (2011) beberapa tindakan pencegahan dan pengendalian yang harus dilakukan adalah mengurangi sumber infeksi, pengawasan sanitasi air, makanan, kendang dan pemberantasan inang perantara atau vector. Pencegahan serta pengendalian penyakit parasite cacing dengan pemberantasan inang perantara atau vector dapat dilakukan secara biologis atau hayati (Nurhidayah, N. et al., 2019). 


\section{Penangan dan pengendalian hayati infeksi parasite pada ternak Kebau di Desa Tanjung Pering}

Terjadi kenaikan tingkat pemahaman ternak tentang cara penanganan ternak yang mengalami infeksi parasite dari 45\% menjadi 85\% (Gambar 2), penanganan yang biasa dilakukan oleh peternak yaitu dengan memberikan obat antibiotik berupa Piperazin, Zanil dan Valbazeni, namun kadang pemberian obat oleh peternak sudah terlambat karena ketidak pengetahuan peternak gejala awal dari ternak yang mengalami infesi parasite cacing, pada saat ternak sudah menunjukkan gejala yang kronis baru peternak memberi obat. Menurut Haryuningtyas dan Beriajaya (2002) pengobatan penyakit parasite cacing dapat dilakukan dengan pemberian obat cacing seperti Ivermectin, Benzimidasol dan levamisole, ditambahkan oleh Koesdarto et al., (2007) selain pengobatan maka Tindakan pencegahan dalam upaya mengurangi infeksi parasite pada ternak perlu dilakukan.

Pengendalian hayati dilihat dari aspek ekologi adalah suatu fase dari pengendalian alami. Definisi pengendalian hayati adalah pengendalian organisme penggangu dengan memanfaatkan agensia pengendali hayati atau musuh alami (Sofislena, 2018). Pengendalian alami mencakup semua pengaturan populasi secara hayati tanpa campur tangan manusia. Sebaliknya jika pengendalian alami secara langsung dan sengaja digunakan untuk pengendalian organisme pengganggu atau jika pernahaman tentang organisme hidup digunakan sebagai dasar untuk strategi atau taktik pengendalian, maka didefinisikan sebagai pengendalian hayati (biological control). Jadi pengendalian hayati adalah manipulasi secara langsung dan sengaja musuh alami, pesaing organisme pengganggu, seluruhnya atau sebagian, atau sumber daya yang diperlukan oleh agen itu untuk pengendalian organisme pengganggu atau dampak negatifnya.

Tingkat pemahaman peternak kerbau di Desa Tanjung Pering tentang pengendalian hayati sangat rendah (35\%), sehingga sebelum dilakukan penerapan atau percontohan pelaksanaan pengendalian hayati dengan menggunakan jamur Nematofagus peternak diberi pengetahuan tentang prinsip utama dan keuntungan yang diperoleh dengan adanya pengendalian hayati sehinga setelah pelaksanaan kegiatan penyuluhan tingkat pemahaman masyarakat meningkat sampai (75\%) (Gambar 2).

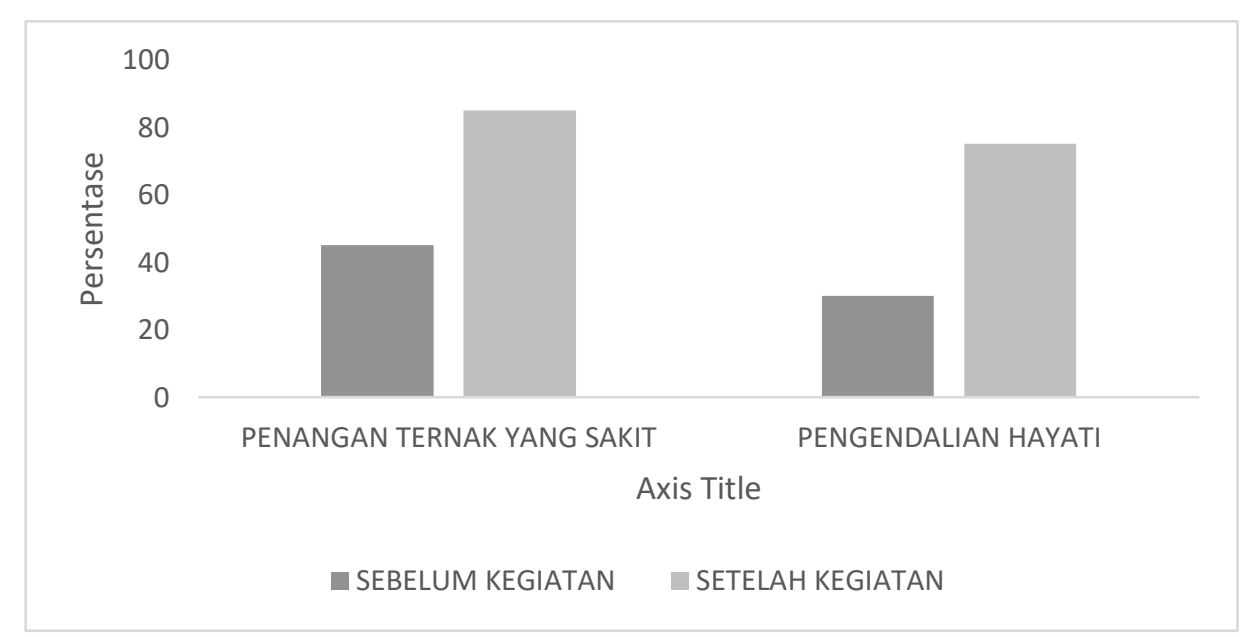

Gambar 2. Tingkat Pemahaman Peternak Tentang Penangan Ternak dan Pengendalian Hayati 
Salah satu agen hayati yang digunakan dalam kegiatan pengendalian penyakit parasitologis pada ternak kerbau di Desa Tanjung Pering adalah jamur Nematofagus. Jamur Nematofogus termasuk dalam kelompok heterogenous jamur mikro, ditandai dengan kemampuan menangkap dan mengeksploitasi nematoda baik sebagai sumber utama makanan atau suplemen kepada kelangsungan saprofitik. Jamur Nematofagus memiliki kemampuan yang berbeda dalam saprofit/parasitnya. Inel C. S., et al., (2020) menyatakan banyak dari jamur Nematofagus pembentuk perangkap dan parasit telur dapat bertahan hidup di tanah secara saprofit dan sebagian besar yang endoparasit lebih banyak bergantung pada nematoda sebagai nutrisi (parasit obligat) salah satunya adalah $M$. eudermatum yang mampu mengendalikan nematodq dilapangan dan mampu menjadi agen hayati berkelanjutan. Berbagai agen hayati memiliki kemampuan menangkap nematoda terkait dengan fase perkembangan spesifik miselium jamur (Pandit, 2014). Kemampuan menangkap nematoda terkait dengan fase perkembangan spesifik miselium jamur. Jamur penjebak (predator) telah mengembangkan struktur hifa, seperti jaring hifa, kenop, cabang atau cincin, di mana nematoda ditangkap oleh adhesi atau secara mekanis. Endoparasit, di sisi lain tangan, menyerang nematoda dengan sporanya, yang menempel di permukaan nematoda atau ditelan olehnya. Terlepas dari metode infeksi, hasilnya selalu sama yaitu kematian nematod (Herzt et al., 2014). Kasim dan Dragh (2016) menyatakan bahwa berdasarkan proses predasi maka jamur Nematofagus dibagi dua kelompok ekologis. Pertama, kelompok predasi, padanya mempunyai struktur perangkap nematoda yang khas (melekat atau tidak melekat) dibentuk pada myselium; dan kedua, kelompok endoparasitik, menginfeksi nematoda dengan spora berperekat melekat kepermukaan kutikula nematoda atau dengan spora kecil yang dimakan oleh nematoda. Pada kegiatan ini peternak juga di beri penjelasan cara pembuatan bolus Nematofaagus sehingga mudah untuk aplikasinya di lapangan.

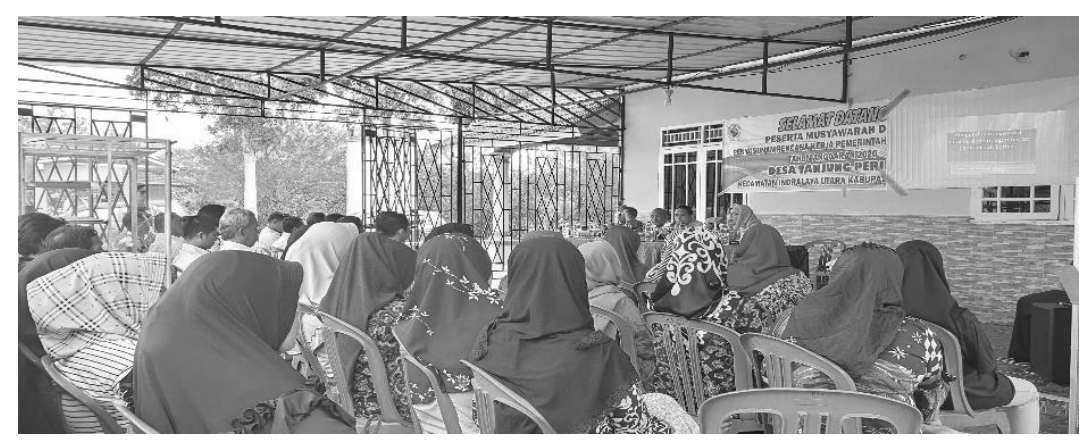

Gambar 3. Peyuluhaan tentang pengendalian hayati penyakit parasitologis

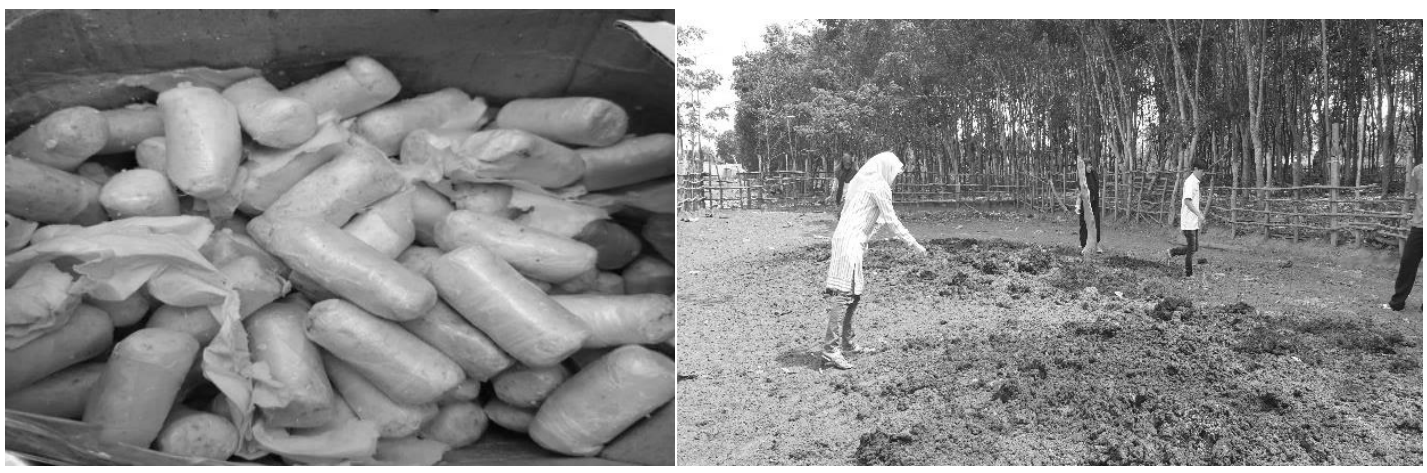

Gambar 4. Penyebaran spora jamur Nematofaagus di sekitar kendang 
Penggunaannya efektif untuk pengendalian cacing nematoda di padang gembalaan atau rumput. Aplikasi peroral dapat dilakukan dengan mencampur pada pakan konsentrat atau diminum dengan air, diberikan selama tujuh hari setiap bulan selama enam bulan. Langsung dipakai di padang gembalaan atau rumput dengan cara bolus dihancurkan dahulu lalu disebarkan di padang gembalaan pada sore menjelang malam hari. Pemberian dilakukan empat kali sebulan dengan dosis satu bolus untuk $4 \mathrm{~m} 2$.

Formulasi bolus ini bekerja dengan cara: (Pertama) Bolus yang mengandung spora klamidospora $D$. flagrans (F.0236) yang telah dikonsumsi ternak masuk ke dalam saluran pencernaan, dan kemudian pada akhirnya akan disekresikan bersama feses di padang gembalaan atau rumput. Bolus yang telah dihancurkan disebarkan langsung pada padang gembalaan atau rumput. Spora dan klamidospora tersebut akan tumbuh dan berkembangbiak dan selanjutnya akan membuat jerat cacing nematoda di padang gembalaan atau rumput. Hanya nematoda dalam bentuk stadium larva yang dijerat dan pada akhirnya akan mati. Jumlah populasi cacing nematoda dapat berkurang jumlahnya hingga mencapai $90 \%$ dari jumlah awal di padang gembalaan sehingga tidak berbahaya lagi untuk ternak yang merumput atau digembalakan. Jinkui (2011) dan Junwei et al., (2013) menyatakan bahwa jamur Nematofagus menangkap nematoda dengan aktif dengan cara membentuk cincin non konstriktif, selain itu nematofagus juga memiliki metabolit sekunder yang dapat merusak kutikula nematoda. Usaha menggunakan jamur nematofagus untuk mengendalikan larva stadium tiga yang hidup bebas dari kelompok cacing Trichostrongylids pada lapangan rumput, dapat dilakukan dalam dua kategori yang berbeda: a) Menyebar dalam jumlah besar jamur yang diperbanyak. Strategi ini memerlukan penyebaran yang banyak material jamur, mungkin beberapa kali musim penggembalaan untuk meyakinkan perlunya level yang tinggi perbanyakan dari jamur agen pengendali hayati.

\section{KESIMPULAN DAN SARAN}

\section{Kesimpulan}

Pada kegiatan pengabdian di Desa Tanjung Pering dapat disimpulkan bahwa:

1. Terjadinya peningkatan pemahaman peternak tentang penyebab penyakit parasite pada ternak kerbau, gejala, cara penanganan dan pengendalian dengan menggunakan agen hayati jamur Nematofagus setelah kegiatan pengabdian dilakukan.

2. Berdasarkan hasil penyebaran spora Nematofagus disekitar kandang kerbau rawa terlihat spora tumbuh dengan baik.

3. Inovasi pengendalian penyakit infeksi parasite pada ternak kerbau di Desa Tanjung Pering berjalan dengan baik, hal ini terlihat dari semua peternak kerbau di Desa Tanjung Pering telah menerapkan agen hayati berupa jamur Nematofagus di sekitar kendang dan padang pengembalaam ternak untuk pengendalian penyakit infeksi parasite pada ternak kerbau.

\section{Saran}

Disarankan pada setiap peternak untuk melakukan kegiatan pengendalian hayati secara reguler dalam waktu 6 bulan sekali terutama dalam waktu akan memasuki musim hujan. 


\section{Daftar Pustaka}

1. Gayatri, S., \& Vaarst, M. (2015). The implementation of Indonesia's beef self-sufficiency programme (BSSP) as seen from a farmerfamily perspective. Journal of Rural and Community Development 10(2), 166-186. https://journals.brandonu.ca/jrcd/article/view/1140

2. Haryuningtyas, D., \& Beriajaya. (2002). Metode resistensi terhadap antelmintik pada Domba dan Kambing. Wartazoa, 12(2), 72-79. file:///C:/Users/AFNUR\%20IMSYA/Downloads/769-787-1PB\%20(1).pdf

3. Hertz, B.N., H. B. Jansson \& Ander Tunlid. (2011). Nematofagus Fungi. Environmental and Mucrobial Relathioship, 247-267. https://doi.org/10.1002/9780470015902.a0000374.pub3

4. Inel. C.S., N. Akhsan \& Suryadi. (2020). Eksplorasi jamur Nematofagus dari pupuk kendang di kota Samarinda: Studi Kasus Kelurahan Lempake. Jurnal agroejoteknologi Tropika Lembab, 3(1), 55-60. DOI: http://dx.doi.org/10.35941/jatl.3.1.2020.3864.55-60

5. Jinkui Y, Wang L, Ji X dan Feng Y. (2011). Genomic and proteomic analyses of the fungus Arthrobotrys oligospora provide insights into nematode-trap formation. Plos pathogens, 7(2), 112. DOI: https://doi.org/10.1371/journal.ppat.1002179

6. Junwei, W., M. Qingling., Q. Jun., W. Weisheng., C. Shuangqing., L. Jianxun., Z. Chunguang., \& C. Chuangfu. (2013). The recombinant serine protease XAoz1 of Arthrobotrys oligospora exhibits potent nematicidal activity against Caenorhabditis elegans and Haemonchus contortus, FEMS Microbiology Letters, 344(1), 53-59. DOI: https://doi.org/10.1111/1574-6968.12154

7. Kasim AA \& Dragh M. (2016). Identification of nematode trapping fungus Monacrosporium eudermatum based on genetic diversity using RAPD technique. American Journal of Microbiological Research, 4(6), 178- 180. DOI: https://doi.org/10.12691/ajmr-4-6-4

8. Koesdarto, S., S. Subekti, S. Mumpuni., H. Puspitawati., \& Kusnoto. (2007). Buku Ajar Ilmu Penyakit Nematoda Veteriner. Fakultas Kedokteran Hewan Universitas Airlangga. Surabaya

9. Nurhidayah Nanis, Fadjar Satrija, Elok Budi Retnani, Dewi Apro Astutim Sri Murtini. (2019). Prevelensi dan faktor resiko infeksi parasite saluran pencernaan pada kerbquvlumpur di Kabupaten Brebeswa Tengah. Jurnal Veteriner, 20(4), 572-582. 5665. DOI: https://doi.org/10.19087/jveteriner.2019.20.4.572

10. Pandit R, Kunjadia P, Mukhopadhyaya P., \& Kunjadia A. (2014). Inorganic phosphate solubilizing potential of Arthrobotrys Conoides and Duddingtonia Flagrans, a nematode trapping fungi a potential biocontrol agent. International Journal of Agricultural Technology, 10(3), 559570 .

http://www.ijataatsea.com/pdf/v10_n3_14_May/5_IJAT_2014_10(3)_Ramesh_Pandit_Anju_Bio control.pdf

11. Sofislena. (2018). Pengendalian Hayati Dengan Memberdayakan Potensi Mikroba. Mulawarman University Press. Edisi I (Oktober 2018).

12. Subekti, S., S. Mumpuni., S. Koesdarto., H. Puspitawati., \& Kusnoto. (2011). Buku Ajar Penyakit Helminth. Airlangga University Press. Surabaya

13. Tampubolon, M. P. (2004). Prospek pengendalian penyakit parasitic dengan agen hayati. Wartazoa, 14(4), 173-177.

https://medpub.litbang.pertanian.go.id/index.php/wartazoa/article/view/798

14. Tiuria, R., Jimmy, P., Ripta, M. N., Bambang, P. P., Adhi, R. H. (2008). Prevalence of trematodes in javan rinochos and banteng in Ujung Kulon National Park. Jurnal Veteriner, 9(2), 94-98. https://ojs.unud.ac.id/index.php/jvet/article/view/3320/2365

15. Widyana, I. G. (2013). Prevalensi Infeksi Parasit Cacing Pada Saluran Pencernaan Sapi Bali Dan Sapi Rambon Di Desa Wosu Kecamatan Bungku Barat Kabupaten Morowali. Jurnal AgroPet, 10(2), 39-46. https://ojs.unsimar.ac.id/index.php/AgroPet/article/view/15

16. Windusari, Y. L. Hanum, M. Kamal, E. Nofiyana, A. Setiawan dan R. Pratama. (2018). Potensi dan Habitat Kerbau Rawa.Noerfikri Offset. Cet: I. Palembang. 